\title{
Effect of Growth Regulators and Biofertilizers on Germination and Seedling Growth of Aonla (Emblica officinalis Gaertn)
}

\author{
M.R. Chiranjeevi, B.M. Muralidhara", M.K. Sneha and Shivan and Hongal \\ Department of Fruit Science, Post Graduate Centre, GKVK Campus, \\ Bengaluru-560 065, Karnataka, India \\ *Corresponding author
}

\section{A B S T R A C T}

\begin{tabular}{|l|}
\hline Ke y w or d s \\
Growth regulators, \\
Biofertilizers, \\
Seedling growth. \\
\hline Article Info \\
\hline Accepted: \\
12 October 2017 \\
Available Online: \\
10 December 2017 \\
\hline \hline
\end{tabular}

An experiment was conducted to know the influence of growth regulators, chemicals and biofertilizers on germination, seedling growth and vigour attributes of aonla. The growth regulators ( $\mathrm{GA}_{3}$ and NAA) chemicals $\left(\mathrm{KNO}_{3}\right)$ and biofertilizers (Azospirillum, Azotobactor, PSB and VAM) were used as treatments at different concentrations. The seeds pre-soaked with $\mathrm{GA}_{3} 200 \mathrm{ppm}$ solution recorded the earliest germination (8.33 days), highest germination percentage $(88.88 \%)$, faster rate of germination (1.07), maximum seedling height (28.47 $\mathrm{cm})$, seedling stem girth $(1.26 \mathrm{~cm})$, seedling biomass $(2.28 \mathrm{~g})$ and highest vigour index of seedlings (202.6) compare to other treatments. In conclusion, soaking of aonla seeds in $\mathrm{GA}_{3} 200 \mathrm{ppm}$ solution for 12 hours followed by 12 hours shade drying will improves the seed germination characters and seedling attributes.

\section{Introduction}

Aonla or Indian gooseberry (Emblica officinalis Gaertn) belongs to the family Euphorbiaceae and is native to tropical regions of South East Asia, particularly Central and Southern India (Mortan, 1990).

Aonla is a rich source of vitamin- $\mathrm{C}$ and also a fair source of minerals particularly iron, phosphorus, calcium and magnesium.

It is generally used for Ayurvedic medicines or processed into quality edible products. In the recent years, considering its prospects particularly in the wasteland situation, area under aonla cultivation is increasing rapidly.
Availability of quality planting material is one of the major problems for expansion of area. Therefore, there is an urgent need to standardize the nursery techniques for improving germination and growth of seedlings. Aonla being a minor fruit crop, less work has been taken for enhancing seed germination and seedling growth by using the plant growth regulators and nutrients.

The present experiment was planned to obtain quicker and higher percentage of germination of aonla seeds by employing pre-sowing treatment with growth regulators and biofertilizers. 


\section{Materials and Methods}

The study was conducted at the Regional Horticultural Research and Extension Centre, University of Horticultural Sciences campus, Vidyaranyapura, Bengaluru to study the effect of plant growth regulators, chemicals and biofertilizers on seed germination, growth and vigour traits.

The local aonla seeds were collected from Aranya Bhavan, $18^{\text {th }}$ cross, Malleshwaram, Bangalore-560003 during the month of November. Seedlings were raised in polythene bags with potting mixture of red soil, sand and FYM (2:1:1).

Thirty six seeds were sown per treatment at the depth of $1-2 \mathrm{~cm}$ below the soil surface. Out of these fifteen plants were tagged to record the observations for seedling traits. The observations were recorded for number of days taken for initiation of germination, germination percentage, rate of germination, plant height, plant girth, number of leaves, seedling vigour and seedling biomass. Percentage of germination was calculated by the following formula.

Number of seeds germinated Germination percentage $=$--------------- $\mathrm{x} 100$

Number of seed sown

The Rate of germination was calculated by using the formula suggested by Maguire (1962). The vigour index was calculated in two ways by considering both length of the seedlings (Vigour index I) and dry weight of the seedling along with per cent germination (Vigour index II) (Abdul Baki and Anderson, 1973).

Vigour index I $(\mathrm{cm})=$ Seedling length (shoot length + root length) $\mathrm{x}$ per cent germination. Vigour index II $(\mathrm{g})=$ Dry weight of seedling $\mathrm{x}$ per cent germination

\section{Treatment details and statistical analysis}

The experimental design was CRD and there were fifteen treatments which are replicated thrice. The treatment details are $\mathrm{T}_{1^{-}}$Control, $\mathrm{T}_{2^{-}} \mathrm{GA}_{3} 200 \mathrm{ppm}, \mathrm{T}_{3}-\mathrm{GA}_{3} 300 \mathrm{ppm}, \mathrm{T}_{4}-$ NAA $200 \mathrm{ppm}, \mathrm{T}_{5}$ - NAA $300 \mathrm{ppm}, \mathrm{T}_{6}-\mathrm{KNO}_{3}$ $1 \%, \mathrm{~T}_{7}-\mathrm{KNO}_{3} 2 \%, \mathrm{~T}_{8}$ - Azospirillum $(15 \mathrm{~g} / \mathrm{Kg}$ of seeds), $\mathrm{T}_{9}$ - Azotobactor (15g/Kg of seeds), $\mathrm{T}_{10^{-}}$Vesicular Arbuscular Mycorrhiza (VAM), $\mathrm{T}_{11^{-}}$Phosphate Solubilising Bacteria (PSB) $\left(15 \mathrm{~g} / \mathrm{Kg}\right.$ of seeds), $\mathrm{T}_{12}$ - Azospirillum + Phosphate Solubilising Bacteria (PSB) (7.5g each/Kg of seeds), $\mathrm{T}_{13^{-}}$Azospirillum + Vesicular Arbuscular Mycorrhiza (VAM) (7.5g each $/ \mathrm{Kg}$ of seeds), $\mathrm{T}_{14-}$ Azospirillum + PSB + VAM (5g each $/ \mathrm{Kg}$ of seeds), $\mathrm{T}_{15^{-}}$ Azotobactor+ PSB + VAM (5g each $/ \mathrm{Kg}$ of seeds). The aonla seeds were soaked in growth regulators and chemicals for $12 \mathrm{hrs}$ and treated seeds were shade dried for 12 hours. For biofertilizers inoculation, fifteen grams of inoculants were mixed with $20 \mathrm{ml}$ of jaggery solution to make slurry. The seeds were mixed with slurry so as to form a uniform coating of the inoculants over the seeds and then shade dried for 30 minutes.

The experimental values were analyzed statistically by using completely randomized block design (CRD) with three replications of each cultivar. Means were compared using WASP (WEB Agri Stat Package ICAR Research Complex, Goa) test at 5\% level of significance.

\section{Results and Discussion}

The seeds treated with $\mathrm{GA}_{3} 200 \mathrm{ppm}$ for 12 hours recorded earliest germination (8.33 days) which was significantly higher than all other treatments (Table 1). This was on par with seeds treated with $\mathrm{KNO}_{3}(1 \%)$ for 12 hours (9.67 days). The late germination was noticed in control, which took 17 days for initiation of germination. The treatment with 
$\mathrm{GA}_{3} @ 200$ ppm for 12 hours of soaking proved to be the best treatment. The exogenous application of Gibberlic acid antagonizes the ill effect of inhibitors (Brain and Hemming, 1958 and Wareing et al., 1968) and increases endogenous gibberellin like substances (Mathur et al., 1971). GA 3 helps in the synthesis of enzymes and one of them is $\alpha$-amylase which converts the starch into simple sugars during the process of germination.

These sugars provide energy that is required for various metabolic and physiological processes associated with germination. Other enzymes activated by Gibberlic Acid include those which weaken the seed coat and allow the axis to burst through. Gibberlic Acid also enhances cell elongation, so the radical can push through the endosperm and seed coat that restrict its growth (Hartman and Kester, 1979). In similar way, Gholap et al., (2000) observed better germination and seedling growth with $\mathrm{GA}_{3} 200 \mathrm{ppm}$ in aonla. Similar results were also obtained by Dhankhar and Singh (1996) in aonla and Muralidhara et al., (2015) in mango.

The seeds treated with $\mathrm{GA}_{3} 200 \mathrm{ppm}$ for 12 hours recorded highest germination percentage $(88.88 \%)$ whereas, the lowest germination recorded in control (52.67\%). The higher seed germination percentage in $\mathrm{GA}_{3}$ was due to instigative action of $\mathrm{GA}_{3}$ for germination of seeds. $\mathrm{GA}_{3}$ induces the $d e$ novo synthesis of proteolytic enzymes like $\alpha$ amylase and ribonuclease.

Amylases in turn hydrolyse starch in the endosperm, providing the essential sugars for the initiation of growth processes (Copeland and Mc- Donald, 1995). GA 3 treatment is also known to overrule the photo dormancy, thermo-dormancy, dormancy imposed by incomplete embryo development, mechanical barriers and presence of germination inhibitors (Diaz and Martin, 1971). The result was in agreement with findings of Praveen $e t$ al., (2006) in Annona squamosa and Muralidhara et al., (2015) in mango.

The seeds treated with $\mathrm{GA}_{3} 200 \mathrm{ppm}$ for 12 hours was recorded faster rate of germination (1.07) which was on par with seeds treated with $\mathrm{KNO}_{3}(1 \%)$ for 12 hours (1.01) and the slow rate of germination was noticed in control (0.28). The Presowing treatments enhanced rate of germination due to increased germination percentage as well as faster and quick germination in aonla. These can be commercially used to increase rate of germination in aonla seeds, which looses viability in long run. In recalcitrant seeds, which are having low germination percent and germination rate, these presowing treatments can be used to increase germination percent and rate of germination. The relative advantage of treating the mango stones, with growth regulators before sowing to reduce the period taken for germination and to remove the obstruction of embryo growth had been reported by Muralidhara et al., (2015), Venkata and Reddy (2005), Padma and Reddy (1998) and Shalini et al., (1999).

At 120 days after sowing, the treatment with $\mathrm{GA}_{3} 200 \mathrm{ppm}$ had recorded the maximum seedling height $(28.47 \mathrm{~cm})$ which was on par with $\mathrm{KNO}_{3}$ (1\%) with $26.53 \mathrm{~cm}$ (Table 2) whereas minimum was in control $(19.07 \mathrm{~cm})$. Basically seedling height is a genetically controlled character. But, several studies have indicated that it can be increased by application of synthetic plant growth regulators. However, in the present investigation a significant difference in seedling height was noticed among the treatments by the application of different plant growth regulators and biofertilizers used. It is interesting to note that, there was an increase in seedling height over control in all the treatments. 
Table.1 Effect of growth regulators and biofertilizers on seed germination traits of aonla

\begin{tabular}{|l|c|c|c|}
\hline Treatments & $\begin{array}{c}\text { Days taken for initiation } \\
\text { of germination }\end{array}$ & Germination $(\%)$ & Rate of germination \\
\hline $\mathrm{T}_{1}$ & 17.00 & 52.67 & 0.28 \\
\hline $\mathrm{T}_{2}$ & 8.33 & 88.88 & 1.07 \\
\hline $\mathrm{T}_{3}$ & 10.00 & 80.55 & 0.91 \\
\hline $\mathrm{T}_{4}$ & 11.67 & 77.22 & 0.84 \\
\hline $\mathrm{T}_{5}$ & 11.00 & 75.00 & 0.86 \\
\hline $\mathrm{T}_{6}$ & 9.67 & 86.11 & 1.01 \\
\hline $\mathrm{T}_{7}$ & 10.67 & 83.33 & 0.95 \\
\hline $\mathrm{T}_{8}$ & 13.00 & 66.55 & 0.66 \\
\hline $\mathrm{T}_{9}$ & 13.67 & 69.33 & 0.70 \\
\hline $\mathrm{T}_{10}$ & 12.00 & 77.77 & 0.76 \\
\hline $\mathrm{T}_{11}$ & 12.67 & 75.00 & 0.72 \\
\hline $\mathrm{T}_{12}$ & 11.67 & 66.66 & 0.66 \\
\hline $\mathrm{T}_{13}$ & 11.33 & 63.77 & 0.61 \\
\hline $\mathrm{T}_{14}$ & 12.33 & 69.44 & 0.65 \\
\hline $\mathrm{T}_{15}$ & 10.33 & 77.78 & 0.74 \\
\hline $\mathrm{F}$ test & $*$ & $*$ & $*$ \\
\hline $\mathrm{SEm} \pm$ & 0.45 & 5.47 & 0.02 \\
\hline $\mathrm{CD}(0.05)$ & 1.35 & 16.41 & 0.06 \\
\hline
\end{tabular}

Table.2 Effect of growth regulators and biofertilizers on seedling growth and vigour of aonla

\begin{tabular}{|l|c|c|c|c|c|}
\hline Treatments & $\begin{array}{c}\text { Seedling } \\
\text { height }(\mathbf{c m})\end{array}$ & $\begin{array}{c}\text { Seedling stem } \\
\text { girth }(\mathbf{c m})\end{array}$ & No. of leaves & $\begin{array}{c}\text { Seedling } \\
\text { biomass }(\mathbf{g})\end{array}$ & $\begin{array}{c}\text { Seedling } \\
\text { vigour }(\mathbf{g})\end{array}$ \\
\hline $\mathrm{T}_{1}$ & 19.07 & 0.96 & 14.15 & 0.90 & 47.40 \\
\hline $\mathrm{T}_{2}$ & 28.47 & 1.26 & 24.28 & 2.28 & 202.60 \\
\hline $\mathrm{T}_{3}$ & 25.47 & 1.13 & 21.35 & 1.99 & 160.30 \\
\hline $\mathrm{T}_{4}$ & 19.73 & 1.05 & 21.39 & 1.65 & 127.41 \\
\hline $\mathrm{T}_{5}$ & 22.40 & 1.06 & 21.86 & 1.59 & 118.99 \\
\hline $\mathrm{T}_{6}$ & 26.53 & 1.24 & 22.49 & 2.04 & 175.94 \\
\hline $\mathrm{T}_{7}$ & 25.53 & 1.17 & 27.03 & 2.07 & 172.21 \\
\hline $\mathrm{T}_{8}$ & 21.47 & 1.10 & 22.43 & 1.82 & 121.13 \\
\hline $\mathrm{T}_{9}$ & 21.53 & 1.11 & 22.28 & 1.92 & 133.12 \\
\hline $\mathrm{T}_{10}$ & 21.47 & 1.09 & 21.47 & 1.87 & 145.44 \\
\hline $\mathrm{T}_{11}$ & 21.93 & 1.13 & 21.83 & 1.89 & 141.49 \\
\hline $\mathrm{T}_{12}$ & 22.20 & 1.06 & 22.70 & 1.80 & 119.99 \\
\hline $\mathrm{T}_{13}$ & 21.00 & 1.10 & 22.44 & 1.90 & 121.38 \\
\hline $\mathrm{T}_{14}$ & 22.80 & 1.12 & 22.08 & 2.08 & 144.67 \\
\hline $\mathrm{T}_{15}$ & 22.47 & 1.21 & 23.13 & 2.14 & 166.18 \\
\hline $\mathrm{F}$ test & $*$ & $*$ & $*$ & $*$ & $*$ \\
\hline $\mathrm{SEm} \pm$ & 0.75 & 0.01 & 1.05 & 0.05 & 4.18 \\
\hline $\mathrm{CD}(0.05)$ & 2.26 & 0.03 & 3.15 & 0.15 & 12.54 \\
\hline
\end{tabular}


Application of biofertilizers and plant growth regulators had significant influence on plant height. Among these, $\mathrm{GA}_{3}$ recorded maximum plant height at all the stages. It was due to $\mathrm{GA}_{3}$ effect on elongation of internodes, as $\mathrm{GA}_{3}$ is known to enhance cell elongation (Krishnamoorthy and Sandooja, 1981). The application of growth promoting substances increased the plant height and such effect was due to increased photosynthetic activity, enhancement in the mobilization of photosynthates and change in the membrane permeability (Shukla et al., 1997). The results were in conformity with the observation made by Rashmi et al., (2007), Parameswari and Srimathi (2008) in aonla and Muralidhara et al., (2015) in Mango.

At 120 days after sowing, seed treatment with $\mathrm{GA}_{3} 200 \mathrm{ppm}$ had recorded the maximum seedling stem girth $(1.26 \mathrm{~cm})$ and this was on par with $\mathrm{KNO}_{3}(1 \%)$ with $1.24 \mathrm{~cm}$ whereas, minimum seedling stem girth $(0.96 \mathrm{~cm})$ was noticed in control. The regulation of growth by gibberellins and $\mathrm{KNO}_{3}$ relates almost extensively to its stem elongation properties. Influence of gibberllic acid and potassium nitrate on stem elongation is by two ways. The first way is that, they have direct effect on stem elongation by inducing cell wall loosening, by increasing cell wall extensibility, stimulating the wall synthesis, reducing the rigidity of cell wall and by increasing cell division leading to more growth.

The second way is the indirect effect of these chemicals on stem elongation is by increasing the synthesis of IAA (Leopold and Kriedeman, 1983). The increase in seedling height and girth by application of gibberllic acid and potassium nitrate was also reported by earlier workers Muralidhara et al., (2015), Venkata Rao and Reddy (2005), Padma and Reddy (1998) and Shalini et al., (1999) in mango. Ahmed and Khan (1964) in citrus seedlings Shanta and Rao (1973) in lime seedlings and Reddy and Khan (2001) in khirni.

The maximum number of leaves was noticed in treatment $\mathrm{KNO}_{3}(2 \%)$ with 27.03 leaves which was on par with $\mathrm{GA}_{3} 200 \mathrm{ppm}$ with 24.28 leaves. While minimum was recorded in control (14.15). The production of more number of leaves in $\mathrm{KNO}_{3}$ and $\mathrm{GA}_{3}$ treatments may be due to the vigorous growth induced by the $\mathrm{GA}_{3}$ and $\mathrm{KNO}_{3}$ treatments, more number of branches which facilitates better harvest of sunshine by the plants to produce more number of leaves. Results obtained on this aspect are in agreement with Muralidhara et al., (2015), Venkata (2002), Marie (2001), Shalini et al., (1999), Khobragode et al., (1999) and Padma and Reddy (1998) in mango.

The seedling biomass significantly differed due to invigoration of seeds with regard to different growth regulators and biofertilizers which influenced the seedling biomass. The highest seedling biomass $(2.28 \mathrm{~g})$ was recorded in $\mathrm{GA}_{3} 200 \mathrm{ppm}$ which was on par with Azatobactor + Phosphate Solubilizing Bacteria + Vesicular Arbuscular Mycorrhiza fungal treatment $(2.14 \mathrm{~g})$ whereas; minimum seedling biomass $(0.90 \mathrm{~g})$ was noticed in control. The biomass produced by the plant is the net gain of interplay between various anabolic and catabolic processes in plants. Plant growth regulators, particularly $\mathrm{GA}_{3}$ exhibited profound influence on dry matter accumulation in different plant parts, which could be due to its effect in stimulating cell division, cell elongation, auxin metabolism, cell wall plasticity and permeability of cell membrane leading to enhanced growth. Increase in the dry weight of different plant parts due to biofertilizers could be due to improved soil fertility, thereby rendering more availability of nutrients required for plant growth and development. The results are 
in accordance with Parameshwari et al., (2001) in aonla and Ratan and Reddy (2004) in annona.

The treatment with $\mathrm{GA}_{3} 200$ ppm recorded significantly highest vigour index (202.60 g) while the least vigour index was noticed in control (47.40 g). The highest seedling vigour in $\mathrm{GA}_{3}$ was attributed to enlarged embryos, higher rate of metabolic activity and respiration, better utilization and mobilization of metabolites to growing points and higher activity of enzymes. Enzymatic and hormonal mechanism stimulate metabolic process such as sugar mobilization, protein hydrolysis, oxidation etc. (Earlpuls and Lambeth, 1974), which leads to increase in root length, shoot length and seedling dry weight, in turn increase in seedling vigour. In conclusion, soaking of aonla seeds in $\mathrm{GA}_{3} 200$ ppm solution for 12 hours followed of 12 hours shade drying will improves the seed germination characters and seedling attributes.

\section{References}

Abdual, B.A. and Anderson, J.D., 1973. Vigour determination in soyabean by multiple criteria. Crop Sci., 13: 630-633.

Ahmad, S. and Khan, M.C., 1964. Effect of GA on growth of citrus seedlings Pun Fruit J., 26: 342-346.

Brian, P.W. and Hemming, H.G., 1958. Complementary action of gibberellic acid and auxin in pea internode extension. Ann Bot., 22:1-7.

Copeland, L.O. and Mcdonald, M.B., 1995. Principles of Seed Science and Technology. III Edition-Chapman and Hall Publications, New York, pp 127146.

Dhankhar, G.S. and Singh, M., 1996. Seed germination and seedling growth in aonla (Phyllanthus emblica L.) as influenced by gibberlic acid and thiourea. Crop Res., 12(3): 363-366.

Diaz, D.H. and Martin, G.C., 1971. Peach seed dormancy in relation to inhibitors and applied growth substance. J. Amer. Soc. Hort. Sci., 97(5): 651-654.

Earlpuls, E.J.R. and Lambeth, V.M., 1974. Chemical stimulation of germination rate in aged tomato seeds. J. Anzer. Sac. Hort. Sci., 99(1): 912.

Hartmann, H.T. and Kester, D. E., 1979. Plant Propagation Principles and Practices. Fourth Edition, Prentice Hall of India, Ltd., New Delhi. pp.407.

Khobragade. H. M., Patil. B. N., Patin, S. P. and Belorkar, P. V., 1999. Performance of mango rootstocks under nursery conditions. J. Soils and Crops., 9(2): 244-246.

Krishnamoorthy, H.N. and Sandooja, J.K., 1981. Effect of ethrel and gibberellic acid on growth flowering and sex expression of Cucurbita pepo $\mathrm{L}$. Haryana J. Hort. Sci., 10(3): 249-252.

Leopold, A. C. and Kriedeman, E. T., 1983. Plant girth and development. Tata Mac grow hill Pub. Co. Ltd. New Delhi., pp102.

Maguire, J.D., 1962. Speed of germinationaid in selection and evaluation of seedling emergence and vigour. Crop Sci., 2:176-177.

Marie, C. P., 2001. Dwarfing potential of indigenous mango varieties. M.Sc. Thesis, Kerala Agricultural University, Thrissur.

Mathur, D.D., Couvilon, G.A., Vines, H.M. AND Hendershott, C.H., 1971. Stratification effects on endogenous gibberellic acid in peach seeds. Hort sci., 6: 538-539.

Morton, J. F., 1990. The Emblic (Phyllanthus emblica L.). Economic Botany, 14: 119127.

Muralidhara, B. M., Reddy, Y. T. N., Akshitha, H. J. and Srilatha, V., 2015. Effect of presowing treatments on 
germination, growth and vigour of polyembryonic mango seedlings. Environ. Ecol., 33(3): 1014-1018.

Padma, M. and Reddy, Y.N., 1998. Effect of pre-sowing treatment of stones and kernels on mango (Mangifera indica L.) germination. J. Res. ANGRAU., 26(2): 17-21.

Parameswari, K. and Srimathi, P., 2008. Influence of growth regulators on elite seedling production in tamarind (Tamarindus indica). Legume Research, 31(4): 300-302.

Praveen, J., Reddy, B. S. and Patil, R. T., 2006. Effect of different seed treatments on germination of Annona squamosa L. under misthouse ecosystem, J. Asian. Hort., 2(1/2): 1923.

Rashmi, K. S. S. S., Sehrawat, S. K. and Dudi, O. P., 2007. Germination studies in aonla (Emblica officinalis Gaertn). Haryana J. Hort. Sci., 36(1/2): 9-11.

Ratan, P. B. and Reddy, Y. N., 2003. Influence of potassium nitrate on germination and subsequent seedling growth of custard apple (Annona squamosa L.). J. Res. ANGRAU, 31(4): 70-73.

Reddy, Y. T. N. and Khan, M. M., 2001. Effect of osmopriming on germination, seedling growth and vigour of khirni (Mimusops hexandra) seeds. Seed Res.,
29(1): 24-27.

Shalini, P., Bagde, T. R. and Bharti, B., 1999. Growth of mango (Mangifera indica $\mathrm{L}$.) seedlings as influenced by stone treatment. J. Soils \& crops, 9(2): 227230.

Shanta, P. S. and Rao, S. N., 1973. Note on the effect of GA on seed germination and seedling girth of acid lime (Citrus aurantium). Prog. Hort., 5(3): 63-65.

Shukla, K.C., Singh, O.P. and Samaiya, P.K., 1997. Effect of foliar spray of plant growth regulator and nutrient complex on productivity of soyabean var. JS 79 . Crop Res 19: 213-215.

Venkata R., 2002. Studies on nursery and propagation techniques in polyembryonic rootstocks of mango (Mangifera indica L.). M.Sc. (Hort.) Thesis, University of Agricultural Sciences, Bangalore.

Venkata, R. and Reddy, Y.T.N., 2005. Effect of osmopriming on germination, seedling growth and vigour of mango (Mangifera indica L.) stones. The Kar. J. Hort., 1(4): 29-35.

Wareing, C., Brewbaker, B. and Crawford, D.J., 1968. The activity of endogenous growth regulators in lettuce in relation to seed germination. Amer. J. Bot., 54: 314-317.

\section{How to cite this article:}

Chiranjeevi, M.R., B.M. Muralidhara, M.K. Sneha and Shivanand Hongal. 2017. Effect of Growth Regulators and Biofertilizers on Germination and Seedling Growth of Aonla (Emblica officinalis Gaertn). Int.J.Curr.Microbiol.App.Sci. 6(12): 1320-1326.

doi: https://doi.org/10.20546/ijcmas.2017.612.149 